\title{
The meaning of institutional logics for performance assessment in
}

\section{boards of municipal companies}

\author{
Trude Høgvold Olsen \\ Associate professor, PhD \\ Trude.h.olsen@uit.no \\ School of Business and Economics \\ UiT The Arctic University of Norway \\ Mailbox 1063 \\ N-9480 Harstad \\ Elsa Solstad \\ Associate professor, Dr. \\ Elsa.solstad@uit.no \\ School of Business and Economics \\ UiT The Arctic University of Norway \\ Mailbox 1063 \\ N-9480 Harstad \\ Harald Torsteinsen (corresponding author) \\ Professor, Dr. \\ Harald.torsteinsen@uit.no \\ Department of Sociology, Political Science and Community Planning \\ UiT The Arctic University of Norway \\ Mailbox 1063 \\ N-9480 Harstad \\ Norway \\ Phone: +47 77058220 (office) +4795207740 (cell)
}

\section{Summary}

Municipal companies are hybrid organizations hosting multiple institutional logics operating at the interface between the public and private sector. We propose an analytical framework inspired by the institutional logics perspective, which can help us understand how performance assessment in municipal corporate boards develops as they navigate between the interests of the owner, the external stakeholders and the company.

Keywords: municipal companies, boards, institutional logics, hybridization, performance 
Introduction

During the last decades, we have witnessed a considerable growth in municipal companies in many Western countries, often labelled corporatization (Aars and Ringkjøb, 2011; Grossi and Reichard, 2008; Grossi et al., 2015; Wollmann and Marcou, 2010). Some municipal companies operate in commercial markets in competition with private businesses (for example parking and industrial waste), others in regulated quasi-markets (for example household waste). On the one hand, municipal companies may serve local politicians as alternative instruments to traditional public administration for the delivery of public services. On the other hand, they form discrete bodies, formally separated from the municipal administration and the authority of the municipal chief executive officer (CEO). They have a high, although varying degree of autonomy, they make decisions through their own boards, and normally they have to provide for their own revenues and expenses. This means that 'instead of direct hierarchical control by a government unit, boards have been installed to govern or oversee the organization' (Van Thiel, 2015: 322). The appointment of boards thereby implies a new and more indirect way of governing public activities, creating a formal barrier between these activities and the elected body, i.e. the local council. However, the 'price' for this freedom is that municipal companies have to accept more performance control (Lægreid et al., 2008), and in this context, performance measurement seems to be an essential component of governing and overseeing the organization (Padovani et al., 2010). Consequently, the boards carry a special responsibility for aligning the performance of the companies with the demands and expectations of the principal(s) and therefore they need access to reliable performance information.

Corporatization implies hybridization of local government (Grossi et al., 2015). At a lower level within this context, we may conceptualize municipal companies as hybrid organizations. By a hybrid organization we understand an organization where two or more institutional logics meet (Battilana and Dorado, 2010; Jay, 2013). Institutional logics may be defined as 'the socially constructed, historical patterns of cultural symbols and material practices, assumptions, values and beliefs by 
which individuals produce and reproduce their material subsistence, organize time and space, and provide meaning to their daily activity' (Thornton et al., 2012: 51). Municipal companies operate at the interface between the public and the private sector, each with their own characteristic institutional logics. Thus, institutional logics can be seen as macro-level societal constructions that shape organizational fields and organizations and influence identities and behaviour of groups and individuals at the micro level. In our setting, institutional logics operate at the community level (the local government and the external stakeholders), the organizational level (the municipal company) and the individual level (the board members). Hence, municipal corporate boards have become meeting places for different institutional logics embedded in a multilevel hybrid system. We assume that actors at the other levels explicitly or tacitly signal their performance expectations to the board. Because each institutional logic influences the assessment of performance (Jay, 2013) the municipal corporate board must address questions of how it should emphasize, prioritize or balance the different institutional logics when discussing performance.

Corporatization represents fundamental changes in local government and has important implications for the development of the public governance system. However, despite the growing prevalence of municipal companies and other hybrid constructions, they have so far attracted limited research interest (Grossi et al., 2015; Ringkjøb et al., 2008). Research on boards of municipal companies and their appointed members is particularly scarce (Ringkjøb et al., 2008; Van Thiel, 2015). However, there is some research on institutional boards, especially in the UK, for instance on boards in the National Health Service (NHS) (Ashburner, 2003; Ferlie et al., 1996; Robinson and Shaw, 2003), local school boards (Farrell, 2005) and boards in central government (Wilks, 2007). Wilks (2007) uses the term 'boardization' about the explicit encouragement in British central government to establish boards modelled on principles of private sector corporate governance. This paucity of research is highly paradoxical given the large scope and growing importance of corporate forms in local government (Aars and Ringkjøb, 2011; Grossi and Reichard, 2008; Grossi et al., 2015; Wollmann and Marcou, 2010). However, recently Van Thiel (2015) developed a useful typology for studying boards 
of public sector organizations. In the same spirit, the purpose of this paper is to develop an analytical framework inspired by the institutional logics perspective (Thornton et al., 2012) in order to understand how multiple institutional logics affect performance assessment in municipal companies. We claim that the board is a central unit of analysis for three reasons: (1) the corporate boards are responsible for both the conformance and performance (Cornforth, 2003) of municipal companies, (2) these boards, since they are composed of individuals carrying different institutional logics are hybrid entities, comprising divergent performance expectations, and thus (3) multiple performance criteria may apply, thereby causing various performance assessments.

We address the following research question: How does the presence of multiple institutional logics affect performance assessment in municipal corporate boards? Our conceptual article contributes to the knowledge of municipal corporate boards by highlighting diverging expectations of company performance. We also demonstrate that the institutional logics perspective may help to understand how boards navigate between diverging expectations and tensions. The paper contributes to the institutional logics literature by exploring the meeting between five institutional logics at the micro level and in a political setting.

The remainder of this paper has the following structure: First, we describe boards in municipal companies before we discuss five institutional logics influencing municipal corporate boards. We then show that the multiple institutional logics imply divergent performance expectations and performance criteria, and finally we discuss possible tensions in municipal corporate boards.

\section{Boards in municipal companies}

As Van Thiel (2015) points out, there are several types of boards in public sector organizations. In this paper, we focus on boards of municipal companies and illustrate our discussion with Norwegian examples. Municipal corporate boards in Norway align with the Anglo-Saxon one-tier system and may encompass both executives and non-executives (archetype II in Van Thiel, 2015: 324). The dominating types of municipal companies are the limited company, the inter-municipal company and 
the municipal firm. The limited company is regulated by the Limited Companies Act, while a special public law regulates the inter-municipal company. Both these company forms have their own legal personality. The municipal firm ('kommunalt foretak'), however, is regulated by the Local Government Act and is an integrated, although relatively autonomous entity with its own board. In the limited company, the annual general meeting (AGM) appoints the board, while in the intermunicipal company this authority rests with the assembly of representatives (AR). If the limited company has only one owner, the mayor often functions as the AGM. The AR of the inter-municipal company usually consists of mayors or senior local politicians from the owner municipalities. In the case of the municipal firm, the local council appoints the board and functions as an AGM. The formal, law-based authority and responsibility of the boards are very strong, especially in the limited company and the inter-municipal company.

The members of municipal corporate boards have different backgrounds (Ferlie et al., 1996). Many of them are councillors (i.e. members of the local council) or former councillors while others are employees, professionals or business people. Lately, several actors have advocated the need for more 'professional' boards, usually meaning fewer politicians and more executives and people with a business background (Ringkjøb et al., 2008). However, opinions on this topic vary along the traditional left-right dimension of politics, but also between municipalities and regions. In the last case, the geographical dimension may trump the political, creating bipartisan consensus (Ringkjøb et al., 2008).

Boards, whether in municipal companies or other companies, shape their role in the triangle between three different stakeholders: the owner, the company and external stakeholders (Moore, 1997; Ringkjøb et al., 2008; Zahra and Pearce, 1989). The municipality (or several municipalities) is (are) the owner(s) of the company. The board in a municipal company has its legal mandate from the local council, which decided to establish the company, and from the laws governing the particular form of municipal company. The owner seldom defines its interests in very exact terms beyond the 
by-laws that the local council passed in relation to the establishment of the company, or any decisions that it makes later in relation to periodic presentations of ownership reports (Ringkjøb et al., 2008; Torsteinsen and Bjørnå, 2012). Even in situations when one single municipality owns a company, the owner may have problems in developing and expressing a clear policy due to cleavages between different political parties. This creates specific challenges for board members (Torsteinsen and Bjørnå, 2012). In order to protect the owner's interests, they have to interpret and operationalize what the owner's intentions with the company are. This may be challenging when diverse institutional logics coexist and suggest diverse performance expectations.

Formally, the board is an integrated part of the corporate structure of the municipal company. In addition to protecting the owners' interests, the board should ensure that the municipal company has or develops a strategy that enables it to perform and fulfil its mission, whether it is to realize projects, deliver services or pay dividends. The management of the municipal company will play an important part in the strategy process because they are involved in the everyday work and are the experts on the specific tasks, service delivery and market conditions. However, the board can choose how involved they would like to be in the strategy process. Diverse institutional logics may have different implications for whether the board should act as a mere 'rubber-stamping' body or play a more active role in the shaping of strategy processes and decisions (McNulty and Pettigrew, 1999).

The board in a municipal company may feel strong obligations toward external stakeholders, for instance users/customers, unions, civic organizations and local communities. Some of these stakeholders have direct access to the board, for example employees, because they have a representative appointed to the board. Other stakeholders work indirectly through the owner, for instance the local council, political parties, local politicians (including the mayor) or the municipal CEO.

The three groups of stakeholders are embedded in different institutional logics and thereby they represent different interests and perspectives. Consequently, they may advocate diverse 
expectations as to what the board should emphasize in terms of performance. We illustrate this triangle of interests in Figure 1. We can link the corners of this triangle to three board roles described in the corporate governance literature: the control role, the strategy role and the service role (Zahra and Pearce, 1989).

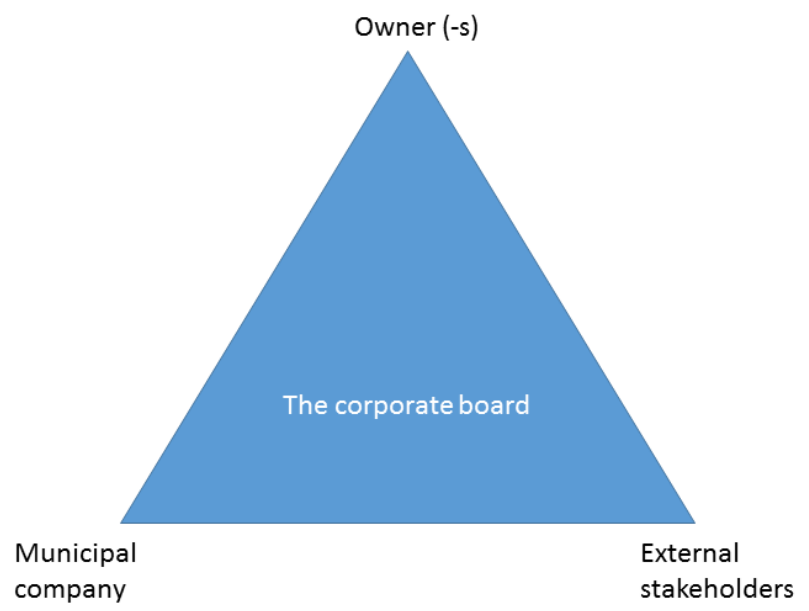

Figure 1. The triangle of interests affecting the municipal corporate board.

The control role concerns the protection of the owners' interests (Huse, 2005). However, in the public sector this role also relates to a democratic perspective (Cornforth, 2003), which implies that the ultimate owner (principal) is the demos, i.e. the citizens. The local council, elected by the citizens, functions on their behalf as owner and it appoints the board members directly (as in the case of a municipal firm) or indirectly (as in the case of a limited company or an inter-municipal company). This means that the structure of principals is multilayered and may seem rather opaque.

Related to the governance of public and non-profit organizations, the board should represent the interests of the client groups served by the organization, even if they do not have attractive resources (Cornforth, 2003). As such, the board's service role contributes to ensure that external stakeholders are heard in the boardroom, for example by board members raising their voice if the municipal company is underperforming (Van Thiel, 2015). The service role of corporate boards describes the board as a boundary-spanning resource provider to the company (Pfeffer, 1972; 
Minichilli et al., 2009), for example through board members' professional networks. Thus, the service role of municipal company boards relates to ensuring important resources, including legitimacy for the company, for example professional and political networks and the competencies and perspectives of clients.

The strategy role has to do with taking care of the municipal company's interests. It supplements the two other roles by focusing on how and to what extent board members are involved in contributing to organizational performance and in the shaping and taking of strategic decisions (Huse, 2007; McNulty and Pettigrew, 1999; Stiles, 2001). The strategy role has been elaborated in recent research due to the board's role in value creation and innovation (Gabrielsson and Politis, 2009; Hoskisson et al., 2002). In the public and non-profit governance tradition, the board's role is symbolic and limited to 'rubber-stamping' management decisions (Cornforth, 2003).

The triple-role orientation of municipal corporate boards (owner, company, external stakeholders) has relevance for the role expectations and the performance expectations that individual board members have to manage. Board members have or develop different orientations, but as individual members of a collective body their orientations will influence and be influenced by others' orientations. The board composition literature has studied observable and underlying attributes of board members and their relation to board task performance (Milliken and Martins, 1996). Examples of observable attributes are gender, race and age. Underlying attributes are, for example, educational, functional and political background. These underlying attributes influence cognitive tasks (Simons et al., 1999) and value judgments. This is relevant in our context because board members' educational, functional and political background may affect which issues they highlight as important, how they understand issues and which roles they enact in the boardroom. In this way, we interpret board members as carriers of institutional logics that will affect the board's performance assessments. 
We assume that boards seek to navigate between these three corners of the triangle and that over time they may adjust their position as circumstances and board composition change, or because of socialization or learning among board members. In the public sector, multiple goals often exist, although they are not always very specific. Besides, 'steering by indicators' is quite unusual, both in Norway and in other countries (Lægreid et al., 2008), thereby giving board members some leeway in the selection and use of performance criteria. This may create ambiguity in performance assessment (Mair et al., 2015). Consequently, because various actors may have different opinions on what is good performance, the boards of municipal companies need to handle tensions, especially when it comes to measuring and evaluating performance.

\section{Institutional logics in municipal corporate boards}

Municipal companies introduce not just corporate forms into local government, but also logics of corporate governance and market principles (Thornton et al., 2012). These logics seem to represent something new and in many respects something different from the logics that have prevailed in local government. In this situation, municipal corporate boards become a focal point for research in terms of being the meeting place for both new and prevailing logics. We here discuss five such institutional logics that to various degrees and in different situations affect the work of the municipal corporate board: the logics of politics and bureaucracy associated with the owner, the logics of corporate governance and market linked to the company, and the community logic related to the external stakeholders. The high number of logics included in our study represents a contribution to the hybridization literature since usually it explores the meeting between only two logics (Greenwood et al., 2011).

The logics of politics and bureaucracy both represent classical features and cultures of the public sector, although they relate to different tasks, responsibilities and institutions within the sector. What characterizes the logic of politics in democracies are the sovereignty of the demos and the intention to solve contradictions of values and interests through dialogue. This includes negotiations, 
alliance building and different types of power games between political parties, representing different ideologies. When dialogue fails, the democratic political logic includes already set-up formal, and generally accepted decision-making procedures to secure the resolution capacity of the system (Petersson et al., 1996). Traditionally, a combination of political competition and cooperation has set its mark on local government. Except for the short periods of political strife, rivalry and haggling associated with local elections every fourth year and the ensuing horse-trading about the distribution of political positions, including appointments to municipal corporate boards, local political life has normally been rather peaceful (Offerdal, 1992). In their role as owners, local politicians expect municipal companies to take care of designated tasks, respond to legitimate needs and interests of external stakeholders, and pay a reasonable dividend to the municipal coffers. These expectations are especially directed to the board members who may easily be replaced if they do not adhere. Some studies indicate that board members with a political background may be more pragmatic and better able to negotiate broad solutions than board members without such an experience (Ringkjøb et al., 2008).

In addition to the logic of politics, local government is permeated by the logic of bureaucracy (Jacobsen, 1997). By bureaucracy, we mean here two things - management by formal rules and management through hierarchy (Torsteinsen, 2012). Both features are designed to secure equity, predictability, democratic control, probity and accountability (Ferlie et al., 1996). The municipal CEO, as the top municipal bureaucrat, carries the prime responsibility for the implementation of plans and decisions made by the local council. In this respect, he/she embodies the link between politics and bureaucracy. Regularly, he/she has to give account to the local council for what the administration and the service delivery bodies have done, how they have done it and with what effects. The establishment of municipal companies challenges these principles by removing activities, resources and personnel from the direct hierarchical control of the municipal CEO. The municipal corporate board takes over this role. Thereby, the line of traditional public bureaucratic accountability is broken. The municipal bureaucrats, including the municipal CEO, conceive of the ownership role in 
terms of compliance and control, but they have few if any formal mandates to intervene. However, the municipal control committee, which is a mandatory political unit in all Norwegian municipalities, has the formal authority to monitor the performance and the conduct of the companies and to report any deviations to the local council (-s) (Inter Municipal Companies Act, 1999; Local Government Act, 1992). In addition, we have the traditional auditing function, which addresses its reports directly to the local council (in the case of a municipal firm) or the AGM and the AR.

The logics of corporate governance and markets represent the core of modern capitalism (Thornton et al., 2012). The market logic is based on the market as a social mechanism where buyers and sellers negotiate prices through balancing supply and demand and where (ideally) no single actor dominates the other actors. One of the most important features of New Public Management (NPM) is the introduction of market principles in public service provision. Inspired by this neo-liberal ideology, the EU has, during the last 30 years, deregulated former public services and exposed them to international market competition (electricity, public transport, telecommunications, waste, water supply etc.). To a certain extent, municipal companies have been tailor-made to meet this competition. The corporate governance logic views the corporation as the organizational and institutional response to market competition. Many municipal companies have gradually developed into large and complex corporations with subsidiaries and cross-ownerships. In this context, boards have to relate to the municipal company and its managing director and respond to his/her performance reports, analyses and proposals. The board also has an initiating and strategic role. The institutional logics of corporate governance and market highlight the interests of the company.

The board also has to keep an eye on the external stakeholders, i.e. clients/customers, partners, competitors, supervisory agencies, community groups, unions and media. This role seems to align with the community logic of Thornton et al. (2012). Communities consist of people and organizations sharing a limited territory that permits numerous contacts and relations beyond what follows from delivering a specific public service. The relations between municipal companies and communities are 
often described as complementary, cooperative and horizontal, based on a foundation of shared values and mutual trust. The legitimacy of the companies depends on their ability and willingness to perform and to provide services of public value (Van Dooren et al., 2010). Therefore, for the board of a publicly owned company, community logic seems to be of pivotal importance.

\section{Institutional logics and performance expectations in municipal corporate boards}

The three groups of stakeholders, embedded in multiple institutional logics, may develop different performance expectations, which they communicate to the municipal companies and their boards, more or less explicitly. Consequently, board members face possible tensions when assessing performance and making decisions. In Table 1, we illustrate possible links between stakeholders, institutional logics, performance expectations and performance criteria, contributing to theoretical and practical understanding of performance assessments in municipal corporate boards.

Table 1 Linking stakeholders, board roles, institutional logics, performance expectations and performance criteria

\begin{tabular}{|c|c|c|c|}
\hline $\begin{array}{l}\text { Stakeholders/ } \\
\text { board roles }\end{array}$ & Institutional logics & $\begin{array}{l}\text { Performance } \\
\text { expectations } \\
\text { (examples) }\end{array}$ & $\begin{array}{l}\text { Performance criteria } \\
\text { (examples) }\end{array}$ \\
\hline $\begin{array}{l}\text { Owner }(-s) / \\
\text { control role }\end{array}$ & Politics and bureaucracy & $\begin{array}{l}\text { - Service quality } \\
\text { - Efficiency } \\
\text { - Transparency } \\
\text { - Probity } \\
\text { - Accountability } \\
\text { - Compliance }\end{array}$ & $\begin{array}{l}\text { - Provision and price } \\
\text { - Dividend } \\
\text { - Information } \\
\text { - No misconduct } \\
\text { - Control mechanisms } \\
\text { - Respecting rules }\end{array}$ \\
\hline $\begin{array}{l}\text { Municipal company/ } \\
\text { strategy role }\end{array}$ & $\begin{array}{l}\text { Corporate governance } \\
\text { and market }\end{array}$ & $\begin{array}{l}\text { - Service quality } \\
\text { - Efficiency } \\
\text { - Competitive } \\
\text { - Attractive } \\
\text { - Financially robust }\end{array}$ & $\begin{array}{l}\text { - Competent \& reliable } \\
\text { - Profitable } \\
\text { - Wins contracts } \\
\text { - Recruits good people } \\
\text { - Able to invest }\end{array}$ \\
\hline $\begin{array}{l}\text { External stakeholders/ } \\
\text { service role }\end{array}$ & Community & $\begin{array}{l}\text { - Service quality } \\
\text { - Responsiveness } \\
\text { - Probity and decency } \\
\text { - CSR* }\end{array}$ & $\begin{array}{l}\text { - Competent \& reliable } \\
\text { - Welcomes criticism } \\
\text { - Behaves properly } \\
\text { - Support civic activity }\end{array}$ \\
\hline
\end{tabular}

*Corporate social responsibility

Because these stakeholders adhering to multiple institutional logics communicate multiple and sometimes diverging performance expectations, boards may have to operate with several 
performance criteria and consequently ask for different types of performance assessments. Although stakeholders sometimes share the same performance expectations, for example service quality, their performance criteria may differ. For politicians, keeping user fees low and citizens satisfied may be more important than securing long-term service quality, which often requires large investments. To the extent that expectations are vague or in conflict, boards have to find out how to select and combine which criteria to use. This challenge resembles processes of hybridization (Battilana and Lee, 2014). Another but related example, which illustrates the challenge of balancing diverse institutional logics, is the discussion of how to spend the last year's surplus of the company. There are at least three possible solutions: pay dividends (owner), use it for investments (municipal company and external stakeholders) or develop the existing service (external stakeholders). There is of course no single correct solution in this case and therefore the board members may play out different logics reflecting their affiliations and role orientations.

Ringkjøb et al. (2008) find that which of the logics come to most influence the thinking and behaviour of boards depends on whether the board members are politicians or not. Local government is an organization where divergent perceptions and opinions on ownership policy, corporate strategy, organizational form and performance emerge regularly in the local council and in the media. It is difficult, if not impossible for the board to ignore such debates and controversies inside its owner organization (-s) and these processes may spill over into the board itself. However, internal strife, neglect and confusion in the owner municipality (or between owner municipalities) may increase the autonomy and discretion of the board.

Local politicians entering municipal corporate boards, view political experience and attachments as legitimate and valuable features of a board member's competence (Ringkjøb et al., 2008: 87). However, the fact that politicians, more than non-politicians, are carriers of the institutional logic of politics does not imply that politicians want to bring party politics into the boardrooms (Ringkjøb et al., 2008: 94). Instead, they play out the logic of politics more in terms of bringing in a specific 
competence for dealing with controversies and finding unifying solutions. Their experience in handling political differences may be helpful in a multiple logics environment like the municipal corporate board. This may be especially relevant in a Nordic local government setting, renowned for its consensualism and pragmatism (Bukve, 2012). Research findings indicate that both politicians and non-politicians shape their roles according to the institutional logics of corporation and market, although the last group do that more so than the first. In addition, the politicians have stronger orientations toward politics and community than do the non-politicians (Ringkjøb et al., 2008).

\section{Discussion}

Performance assessment in hybrid organizations is challenging because multiple institutional logics carry different, sometimes conflicting performance expectations, and in municipal corporate boards these challenges become particularly visible due to the political context. How do the boards address this situation?

When new members are appointed and enter the board for the first time, they are carriers of different logics and different expectations about performance, and consequently they are potential carriers of tensions and conflict. The tension level may vary depending on, for instance, the composition of the board and the board's ability and willingness to discuss openly performance expectations and performance criteria. Nonetheless, over time, board members learn to know each other and the company, and they start to adjust expectations and develop their identities and role orientations (Andersen and Torsteinsen, 2015; Ashburner, 2003; Ferlie et al., 1996; Torsteinsen and Bjørnå, 2012). This could be conceptualized as an institutionalization process (Selznick, 1957) whereby people develop relations, common perspectives and common values, not necessarily in the sense of 'betraying' their logics, but more in terms of agreeing on what rules to play by. Although the board members identify themselves with certain stakeholders and institutional logics, performance expectations are not always clear and mutually exclusive, thereby being open to reinterpretation and modification. This hybridization process may imply a ranking or integration of the logics (Battilana 
and Lee, 2014), for instance by arguing that prioritizing the company's interests will benefit both the owner and the external stakeholders.

Over time, board members change their orientation from being a representative of the owner or the external stakeholders to becoming more and more a director (Ferlie et al., 1996: 139). This change means that boards gradually give more attention to the strategy role and less attention to the control and service roles. As long as operations meet performance expectations, institutional logics may continue to merge or develop some modus of cohabitation, both at the individual and at the board level (Battilana and Lee, 2014). However, if conflicts arise, for example because of public protest, negative media attention, political controversy, or underperformance on important criteria, the integration process may stop. In case of conflict owner intervention has to be taken into account, and in the Norwegian context this happens relatively often (Aars and Ringkjøb, 2011).

Stability in board membership may be good for both owner, stakeholders and company to the extent that boards become competent and independent entities that are able to combine the different institutional logics and balance service, control and strategy considerations in performance assessments. However, stability may also have negative effects if consensus becomes the highest norm and the agenda is dominated by management or an alliance between the company CEO and the chair of the board (Ferlie et al., 1996). Often this will lead to board closure, where transparency and accountability decrease, a development that may seriously harm the control and service role of the board and thereby the interests of the owner and the stakeholders. Eventually, this may also harm the interests of the company (Renå, 2013). To the extent that board stability is linked to prestigious municipal companies that offer remunerations or other benefits to board members, owners' and stakeholders' may question the board's ability to assess the company's performance independently. In these situations, the control and service roles of the board must be taken care of through other mechanisms. One such mechanism is to reduce stability by regular exchange of board members. Another mechanism could be to strengthen the contact between boards and owners and 
between boards and external stakeholders, thus supplementing the role of the annual general meetings.

\section{Conclusion}

We suggest that the analytical framework developed in this paper provides a new and promising framework for understanding what goes on in the boardroom of municipal companies. It draws our attention to how the board measures and assesses performance under the influence of different logics that board members bring with them into the boardroom. Institutional logics link board members to the world outside the boardroom and contain different expectations as to how the board should navigate between the interests of the owner, the external stakeholders and the company. This also implies that within the board there may be diverging views on the municipal company's goals and mission, strategy and performance. Although logics multiplicity underlines the importance of board appointment, it also emphasizes the processes that occur when different institutional logics meet and seek to find a modus vivendi. These processes lay bare the challenges related to satisfying conflicting performance expectations and performance criteria. Empirical studies of such processes can give us useful insights into the inner workings of the boards as well as hybrid organizations more generally (Battilana and Dorado, 2010; Jay, 2013).

Set on this background, the paucity of research is a paradox. One aspect is that the board as an interesting research setting for hybridization processes is not fully utilized. Another aspect, and this is probably the most important, is the seeming neglect of the transformation that is going on with corporatization in local government, when so much power in the public sector is being transferred from open democratically elected bodies to closed appointed boards. Herein lies the basic practical implication of our contribution. The development we have described seems to change local government in many countries into hybrid systems, composed of numerous hybrid organizations where the opacity of boards is just one, but nonetheless an important component. Although 
challenging, this underscores the importance of transparent performance assessments in hybrid settings like municipal corporate boards.

\section{References}

Aars, J. and Ringkjøb, H.-E. (2011), Local democracy Itd. Public Management Review, 13, 6, pp. 825844.

Andersen, O.J. and Torsteinsen, H. (2015), Selskapsreisen: en casestudie av fristilling som innovasjonskatalysator. In O. J. Andersen, T. Bondas and L. Gårseth-Nesbakk (eds) Innovasjon i offentlig tjenesteyting (Fagbokforlaget).

Ashburner, L. (2003), The impact of new governance structures in the NHS. In C. Cornforth (ed.) The Governance of Public and Non-Profit Organisations - What do Boards do? (Routledge).

Battilana, J. and Dorado, S. (2010), Building sustainable hybrid organizations: The case of commercial microfinance organizations. Academy of Management Journal, 53, 6, pp. 1419-1440.

Battilana, J. and Lee, M. (2014), Advancing research on hybrid organizing. Academy of Management, 8, 1, pp. 397-441.

Bukve, O. (2012), Lokal og regional styring (Samlaget).

Cornforth, C. (2003), Introduction. In C. Cornforth (ed.) The Governance of Public and Non-Profit Organisations - What do Boards do? (Routledge).

Farrell, C. (2005), Governance in the UK public sector: the involvement of the governing board. Public Administration, 83, 1, pp. 89-110.

Ferlie, E., Ashburner, L., Fitzgerald, L. and Pettigrew, A. (1996), The New Public Management in Action (Oxford University Press). 
Gabrielsson, J. and Politis, D. (2009), Board control and innovation: an empirical study of small technology-based firms. In M. Huse (ed.) The Value Creating Board. Corporate Governance and Organizational Behavior (Routledge).

Greenwood, R., Raynard, M., Kodeih, F., Micelotta, E.R. and Lounsbury, M. (2011), Institutional complexity and organizational responses. The Academy of Management Annals, 5, 1, pp. 317-371.

Grossi, G., Papenfuss, U. and Tremblay, M.S. (2015), Corporate governance and accountability of state-owned enterprises. International Journal of Public Sector Management, 28, 4/5, pp. 274-285.

Grossi, G. and Reichard, C. (2008), Municipal corporatization in Germany and Italy, Public Management Review, 10, 5, pp. 597-617.

Hoskisson, R.E., Hitt, M.A., Johnson R.A. and Grossman, W. (2002), Conflicting voices: the effects of institutional ownership heterogeneity and internal governance on corporate innovation strategies. Academy of Management Journal, 45, 4, pp. 697-716.

Huse, M. (2007), Boards, Governance and Value Creation: The Human Side of Corporate Governance (Cambridge University Press).

Huse, M. (2005), Accountability and creating accountability: a framework for exploring behavioural perspectives of corporate governance. British Journal of Management, 16, S1, pp. S65-S79.

Inter municipal companies act (1999), LOV-1999-01-29-6.

Jacobsen, D. I. (1997), Administrasjonens makt- om forholdet mellom politikk og administrasjon (Fagbokforlaget).

Jay, J. (2013), Navigating paradox as a mechanism of change and innovation in hybrid organizations. Academy of Management Journal, 56, 1, pp. 137-159.

Local government act (1992), LOV-1992-09-25-107. 
Lægreid, P., Roness, P.G. and Rubecksen, K. (2008), Performance information and performance steering: integrated system or loose coupling? In W. Van Dooren and S. Van de Walle (eds.) Performance Information in the Public Sector (Palgrave Macmillan).

Mair, J., Mayer, J. and Lutz, E. (2015), Navigating institutional plurality: organizational governance in hybrid organizations. Organization Studies, 36, 6, pp. 713-739.

McNulty, T. and Pettigrew, A. (1999), Strategists on the board. Organization Studies, 20, 1, pp. 47-74. Milliken, F. and Martins L. (1996), Searching for common threads: understanding the multiple effects of diversity in organizational groups. Academy of Management Review, 21, 2, pp. 402-433.

Minichilli, A., Zattoni, A. and Zona, F. (2009), Making boards effective: an empirical examination of board task performance. British Journal of Management, 20, 1, pp. 55-74.

Moore, M.H. (1997), Creating public value: strategic management in government (Harvard University Press).

Offerdal, A. (1992), Den politiske kommunen (Samlaget).

Padovani, E., Yetano, A. and Orelli, R.L. (2010), Municipal performance measurement and management in practice: which factors matter? Public Administration Quarterly, 34, 4, 591-635.

Petersson, O., Hermansson, J, Micheletti, M. and Westholm, A. (1996), Demokratirådets rapport 1996. Demokrati och ledarskap. (SNS Förlag).

Pfeffer, J. (1972), Size and composition of corporate boards of directors: the organization and its environment. Administrative Science Quarterly, 17, 2, pp. 218-228.

Renå, H. (2013), Når kontrollen svikter - en studie av tre korrupsjonssaker i norsk kommunesektor. Norsk statsvitenskapelig tidsskrift, 29, 4, pp. 279-308.

Ringkjøb, H.-E., Aars, J. and Vabo, S.I. (2008), Lokalt folkestyre AS. Eierskap og styringsroller i kommunale selskap. Rapport 1/2008. (Rokkansenteret, UIB). 
Robinson, F. and Shaw, K. (2003), Who governs North East England? A regional perspective on governance. In C. Cornforth (ed.) The Governance of Public and Non-Profit Organisations - What do Boards do? (Routledge).

Selznick, P. (1957), Leadership in Administration (Harper \& Row Publishers).

Simons, T., Pelled, H.L. and Smith, K.A. (1999), Making use of difference: diversity debate and decision comprehensiveness in top management teams. Academy of Management Journal, 42, 6, pp. $662-673$.

Stiles, P. (2001), The impact of the board on strategy: an empirical examination. Journal of Management Studies, 38, 5, pp. 627-650.

Thornton, P.H., Ocasio, W. and Lounsbury, M. (2012), The Institutional Logics Perspective. A New Approach to Culture, Structure, and Process (Oxford University Press).

Torsteinsen, H. (2012), Why does post-bureaucracy lead to more formalisation? Local Government Studies, 38, 3, pp. 321-344.

Torsteinsen, H. and Bjørnå, H. (2012), Agencies and transparency in Norwegian local government. Scandinavian Journal of Public Administration, 16, 1, pp. 5-25.

Van Dooren, W, Bouckaert, G. and Halligan, J. (2010), Performance Management in the Public Sector (Routledge).

Van Thiel, S. (2015), Boards of public sector organizations: a typology with Dutch illustrations. International Journal of Public Sector Management, 28, 4/5, pp. 322-334.

Wilks, S. (2007), Boardization and corporate governance in the UK as a response to depoliticization and failing accountability. Public Policy and Administration, 22, 4, pp. 443-460.

Wollmann, H. and Marcou, G. (eds) (2010), The Provision of Public Services in Europe (Edward Elgar). 
Zahra, S.A. and Pearce II, J.A. (1989), Boards of directors and corporate financial performance: a review and integrative model. Journal of Management, 15, 2, pp. 291-334. 